\title{
Chromosome 7q11 Controls Sperm Beat Cross Frequency (BCF) in Mice*
}

\author{
Aniela GOŁAS, Paweł GRZMIL, Christian MÜLLER and Józefa STYRNA
}

Accepted September 6, 2004

\begin{abstract}
GoŁas A., GrZmil P., Müller Ch., Styrna J. 2004. Chromosome 7q11 controls sperm beat cross frequency (BCF) in mice. Folia biol. (Kraków) 52: 211-217.

The aim of this study was to compare the inheritance of the chromosomal SSLP markers with the inheritance of sperm movement parameters in order to map genes responsible for these quantitative traits (QTs). Chromosome 7 and 14 SSLP markers were tested to obtain the strain distribution pattern (SDP) for recombinant inbred (RI) strains developed from two progenitors, $\mathrm{KE}$ and $\mathrm{CBA} / \mathrm{Kw}$, which differ significantly in gamete quality. Sperm motility characteristics were determined using the computer assisted semen analysis (CASA) system. The Map manager software was used in order to assess linkage between the analyzed motility parameters and chromosome regions. The marker regression, interval mapping and permutation tests matched the QT loci of BCF with chromosome $7 \mathrm{q} 11$. The likelihood ratio statistic for this association was 18.1 with $79 \%$ of the total trait variance explained by QTL at this locus. These mapping results suggest that the BCF trait depends on the genetic factor(s) located in this region.
\end{abstract}

Key words: Recombinant inbred strains, quantitative trait, gene mapping, sperm motility, strain distribution pattern, microsatellite markers.

Aniela GOEAS, Pawet GRZMIL, Józefa STYRNA, Department of Genetics and Evolution, Institute of Zoology, Jagiellonian University, R. Ingardena 6, 30-060 Kraków, Poland.

E-mail:grzmil@zuk.iz.uj.edu.pl

Christian MÜLLER, Institute of Human Genetics, University of Göttingen, Heinrich-Düker

Weg 12, 37-073 Göttingen, Germany.

Since Bailey established the use of recombinant inbred strains (RI) for linkage analysis in gene mapping (BAILEY 1971), many sets of RI strains have been widely applied for mapping novel traits (TAYLOR 1978). Genes controlling fertility are the main interest in the authors' Department where KE and $\mathrm{CBA} / \mathrm{Kw}$ inbred strains are maintained. There are several indications that these strains differ significantly in: (1) gamete quality, such as the percentage of abnormal sperm heads, efficiency of sperm select penetration and (2) fertility parameters, such as supplementary spermatozoa in in vivo fertilization (KRZANOWSKA et al. 1995), fertilization efficiency in vivo (KRZANOWSKA 1970) and in vitro (KALETA 1977). Therefore, the set of RI strains was developed from these two progenitors. First strain distribution patterns (SDPs) were made based on biochemical markers (RAFIŃSKI et al. 1991; KRZANOWSKA et al. 1994; STYRNA et al. 1994). Because the cosegregation of the Gpil marker locus on chromosome 7 with the putative gene(s) affecting gamete maturation was proposed (POLAŃSKI 1997) and some preferences in segre- gation of the centromeric region of the $14^{\text {th }}$ chromosome was found (LENARTOWICZ \& WÓJCIK 1998), these chromosomes were used in analysis. For an adequate correlation and linkage analysis, a higher density of markers was needed. Advances in the mouse genome sequencing and mapping project resulted in many polymorphic loci as for e.g. SSLP (simple sequence length polymorphism) that are easy to analyze and are variable among mouse inbred strains. These sequences allowed obtaining a SDP of over 700 loci for standard AXB, BXA RI sets (SAMPSON et al. 1998) and SWXJ RI set (SHULTZ et al. 1996). SDP analysis from RI strains is especially useful for locating quantitative traits.

One of the important parameters influencing fertilization efficiency is sperm motility (OLDS-CLARKE 1986; HIRANO et al. 2001). The understanding of genetic control of sperm movement is very poor. There are a few examples of inherited traits affecting sperm motility (THONNEAU et al. 1991; REN et al. 2001), however, the location of chromosome regions that contribute to this feature in mice are still

*Supported by Jagiellonian University, Institute of Zoology grants BW/21/IZ/2002 and DS/ZG/IZ/2003. 
unknown. A suitable method to characterize sperm movement is the computer assisted semen analysis system (CASA) (KING et al. 2000; SATO et al. 2002). The advantages of this method are that subjective microscopic analysis may be avoided and different sperm movement features can be measured simultaneously. Here, sperm motility parameters were analyzed with CASA in order to find any cosegregation of these characters with chromosomal markers among RI strains by use of the Map Manager QTX v. b18 software (MANLY et al. 2001).

\section{Material and Methods}

\section{Mice}

Adult male mice (3-7 months old) from $\mathrm{KE}$ and $\mathrm{CBA} / \mathrm{Kw}$ inbred strains and from recombinant inbred (RI) strains developed in the authors' Department were used in this study. Of all 11 RI strains, 3 were obtained from original crosses of $\mathrm{CBA} / \mathrm{Kw}$ females with KE males (lines CBXE 17, 21 and 29) and 8 RI strains from reciprocal crosses (lines EXCB 5, 6, 40, 41, 42, 43, 44 and 49). All animals were given the commercial pelleted diet (Labofeed B, Kcynia) and water ad libitum. Light was switched on between $8.00 \mathrm{~h}$ and $20.00 \mathrm{~h}$. All strains passed through at least 20 generations of inbreeding.

\section{PCR}

Genomic DNA was extracted from mouse tails using standard protocol. PCR was performed with
SSLP MIT markers primer sequences obtained from the mouse genome database (MGD, http://www.informatics.jax.org/) (BLAKE et al. 2002; EPPIG et al. 2002). All used markers and the annealing temperatures for each primer pair are given in Table 1 . Thermal cycling was carried out for 30 cycles, denaturation at $94^{\circ} \mathrm{C}$ for 30 s, annealing for $30 \mathrm{~s}$ at temperature depending on primers used and extension at $72^{\circ} \mathrm{C}$ for 30 s in a total volume of $25 \mu \mathrm{l} .10 \mu \mathrm{l}$ of the reaction mixture was electrophoresed on 2 or $3 \%$ agarose gel stained with ethidium bromide.

\section{Sperm motility analysis (CASA)}

Animals were killed by cervical dislocation. Both epididymes were gently squeezed out into IVF medium (MediCult, Jyllinge, Denmark) under liquid paraffin. Samples of sperm were incubated at $37^{\circ} \mathrm{C}$ and $5 \% \mathrm{CO}_{2}$ in air. $13 \mu \mathrm{l}$ of the sperm suspension was placed on a microscope stage heated to $37^{\circ} \mathrm{C}$ after $1.5 \mathrm{~h}$ of incubation. Sperm movement was examined using the CEROS computer-assisted semen analysis system (ver. 10, Hamilton Throne Research, Beverly, Mass.). Seven parameters of sperm motility were calculated for each analyzed sample: ALH (amplitude of lateral head displacement, $\mu \mathrm{m}$ ), BCF (beat cross frequency, Hz), VAP (average path velocity, $\mu \mathrm{m} / \mathrm{s}$ ), VSL (straight line velocity, $\mu \mathrm{m} / \mathrm{s}$ ), VCL (curvilinear velocity, $\mu \mathrm{m} / \mathrm{s}$ ), LIN (linearity, calculated as a ratio of VSL to VCL, expressed in \%), STR (straightness, calculated as a ratio of VSL to VAP, expressed in \%). Each sample measurement consisted of 20 photos,

Table 1

The list of analyzed SSLP MIT markers and the annealing temperatures used in PCR

\begin{tabular}{|c|c|c|c|c|c||}
\hline Chromosome & Marker & $\begin{array}{c}\text { Annealing } \\
\text { temperature }\left({ }^{\circ} \mathrm{C}\right)\end{array}$ & Chromosome & Marker & $\begin{array}{c}\text { Annealing } \\
\text { temperature }\left({ }^{\circ} \mathrm{C}\right)\end{array}$ \\
\hline \hline 7 & D7Mit152 & 55 & 14 & D14Mit78 & 52 \\
\hline 7 & D7Mit340 & 53 & 14 & D14Mit50 & 60 \\
\hline 7 & D7Mit117 & 55 & 14 & D14Mit14 & 58 \\
\hline 7 & D7Mit267 & 50 & 14 & D14Mit140 & 50 \\
\hline 7 & D7Mit309 & 53 & 14 & D14Mit268 & 50 \\
\hline 7 & D7Mit27 & 50 & 14 & D14Mit234 & 59 \\
\hline 7 & D7Mit83 & 55 & 14 & D14Mit6 & 64 \\
\hline 7 & D7Mit120 & 55 & 14 & D14Mit39 & 55 \\
\hline 7 & D7Mit318 & 50 & 14 & D14Mit115 & 56 \\
\hline 7 & D7Mit62 & 50 & 14 & D14Mit92 & 52 \\
\hline 7 & D7Mit301 & 50 & 14 & D14Mit165 & 53 \\
\hline 7 & D7Mit37 & 53 & & & \\
\hline 7 & D7Mit130 & 50 & & & \\
\hline 7 & D7Mit66 & 55 & & & \\
\hline 7 & D7Mit68 & 55 & & & \\
\hline 7 & D7Mit333 & 53 & & & \\
\hline
\end{tabular}


at least 2500 sperms per sample were examined. Three animals of each strain were analyzed.

\section{Statistical analyses}

For statistical testing, data for sperm motility parameters were pooled for each mouse strain. All measured parameters were normalized by natural logarithms to get a linear distribution. Analysis of variance was applied (ANOVA; Statistica 5.0) to find the differences in parameter means between tested strains. First parameter means of KE and $\mathrm{CBA} / \mathrm{Kw}$ progenitor strains were compared and then the mean values of the parameters for each RI strain were tested against respective values determined for the progenitor strain. A significance level of $\mathrm{P}<0.05$ was considered as statistically significant.

\section{Quantitative traits locus (QTL) analysis}

Chromosome screening for QTL was performed using the Map Manager QTX software. The following tests were informative and gave statistically significant results:

- marker regression - tests the association between the genotype of the marker loci and the quantitative trait value; significance of this association is expressed as the likelihood ratio statistic (LRS); the P-value for a single point below 0.001 was accepted to obtain a genome-wide P-value of 0.05 (LANDER \& KRUGLYAK 1995) and was considered to provide evidence of linkage;

- simple interval mapping - evaluates the association between the trait value and the expected contribution of hypothetical QTL at regular intervals between marker loci; it was applied to get the peak likelihood ratio statistic (peak LRS) that expresses the significance of the association;

- permutation test - establishes the critical values for suggestive, significant and highly significant thresholds of the LRSs generated by the marker regression test and the interval mapping procedures and was done in 1-cM steps for 1000 permutations.

\section{Ethics of experimentation}

Experiments were performed in accordance to Polish legal requirements, under the licence provided by the Commission of Bioethics at the Jagiellonian University.

\section{Results}

\section{PCR}

After gel shift analysis of PCR products, the difference in band length between two progenitor strains (KE and $\mathrm{CBA} / \mathrm{Kw}$ ) was observed in 13 of 17 tested SSLP MIT markers on chromosome 7 and 6 of 11 on chromosome 14 . We used these 19 polymorphic markers to investigate all $11 \mathrm{RI}$ strains. The data obtained (Table 2B) were placed in MGD as SDP tables (http://www.informatics.jax.org/, accession number J:84237).

\section{Motility parameters of sperm movement}

The data from CASA analysis are given in Figure 1. ALH and BCF describe sperm head activity; VAP, VSL, VCL measure sperm velocity aspects and two additional characteristics give information about path shape (LIN as the index of deviation of the track from straight line and STR as the index of the progressiveness of the movement). Analysis of variance showed that the progenitor strains differ significantly from each other and then, using the ANOVA test, the sperm motility parameters of RI strains could be classified as inherited from (Table 2A):

(a) $\mathrm{KE}$ or $\mathrm{CBA} / \mathrm{Kw}$ - significantly different from $\mathrm{CBA} / \mathrm{Kw}$ but not from $\mathrm{KE}$ (indicated as $\mathrm{E}$ ) or significantly different from $\mathrm{KE}$ but not from $\mathrm{CBA} / \mathrm{Kw}$ (indicated as $\mathrm{CB}$ )

(b) intermediate - there is no difference between means for RI strains and any of the progenitor strains, indicated as $\mathrm{E} / \mathrm{CB}$

(c) $\mathrm{CBA} / \mathrm{Kw}$-like or KE-like - examined parameter mean value is different from both $\mathrm{KE}$ and $\mathrm{CBA} / \mathrm{Kw}$ strains, but exceeds the value (in plus or in minus) for one of the progenitor strains, indicated as $\mathrm{E}^{*}$ (exceeds the $\mathrm{KE}$ value) or $\mathrm{CB}^{*}$ (exceeds the $\mathrm{CBA} / \mathrm{Kw}$ value).

\section{QTL test}

The chromosome 7 and 14 scan was used to find coinheritance between all analyzed sperm movement parameters (quantitative traits, QT) and MIT markers. The previously described SDP of centromeric heterochromatin of chromosome 14 (LENARTOWICZ \& WÓJCIK 1998) was used as an additional marker. The marker regression test (Map Manager QTX) revealed $\mathrm{P}<0.001$ in two regions on chromosome 7 (Table 3). A Quantitative Trait Locus (QTL) close to D7Mit267 marker (region $7 \mathrm{q} 11$ ) was associated with the BCF trait (with LRS $=16.9$ ) and accounted for $79 \%$ of the total trait 
Table 2

Strain distribution pattern (SDP) of analyzed sperm movement parameters (A) and chromosomal polymorphic marker loci (B). E - trait value/locus form inherited from the KE progenitor strain, $\mathrm{CB}$ - trait value/locus form inherited from the $\mathrm{CBA} / \mathrm{Kw}$ progenitor strain, $\mathrm{E}^{*}$ - trait value exceeding the $\mathrm{KE}$ value, treated as inherited from $\mathrm{KE}$ strain, $\mathrm{CB}^{*}$ - trait value exceeding the $\mathrm{CBA} / \mathrm{Kw}$ value, treated as inherited from $\mathrm{CBA} / \mathrm{Kw}$ strain, $\mathrm{E} / \mathrm{CB}$ - intermediate/heterozygous form. ${ }^{\#-S D P}$ of centromeric heterochromatin of chromosome 14 taken from LENARTOWICZ and WÓJCIK (1998) with author permission.

\begin{tabular}{|c|c|c|c|c|c|c|c|c|c|c|c|c|}
\hline & RI number & 5 & 6 & 17 & 21 & 29 & 40 & 41 & 42 & 43 & 44 & 49 \\
\hline \multirow[t]{8}{*}{ A } & Trait & & & & & & & & & & & \\
\hline & ALH & E & $\mathrm{CB}$ & $\mathrm{CB}^{*}$ & $\mathrm{CB}^{*}$ & $\mathrm{CB}^{*}$ & $\mathrm{CB}^{*}$ & $\mathrm{CB}^{*}$ & $\mathrm{CB}^{*}$ & $\mathrm{CB}^{*}$ & $\mathrm{CB}^{*}$ & $\mathrm{CB}^{*}$ \\
\hline & $\mathrm{BCF}$ & E & $\mathrm{E}$ & E & E & E & E & E & $\mathrm{CB}$ & E & E & E \\
\hline & VAP & E & $\mathrm{CB}$ & $\mathrm{CB}$ & $\mathrm{CB}^{*}$ & $\mathrm{CB}^{*}$ & $\mathrm{CB}^{*}$ & $\mathrm{CB}^{*}$ & $\mathrm{CB}^{*}$ & $\mathrm{CB}^{*}$ & $\mathrm{CB}^{*}$ & $\mathrm{CB}^{*}$ \\
\hline & VSL & E & $\mathrm{CB}$ & $\mathrm{E}$ & $\mathrm{CB}^{*}$ & $\mathrm{CB}$ & $\mathrm{CB}^{*}$ & $\mathrm{CB}^{*}$ & $\mathrm{CB}^{*}$ & $\mathrm{CB}^{*}$ & $\mathrm{CB}^{*}$ & $\mathrm{CB}^{*}$ \\
\hline & VCL & E & $\mathrm{CB}$ & $\mathrm{CB}$ & $\mathrm{CB}^{*}$ & $\mathrm{CB}^{*}$ & $\mathrm{CB}^{*}$ & $\mathrm{CB}^{*}$ & $\mathrm{CB}^{*}$ & $\mathrm{CB}^{*}$ & $\mathrm{CB}^{*}$ & $\mathrm{CB}^{*}$ \\
\hline & LIN & E & $\mathrm{CB}$ & $\mathrm{E}^{*}$ & E & $E^{*}$ & $\mathrm{CB}$ & $\mathrm{CB}$ & $\mathrm{CB}$ & E & E & $E^{*}$ \\
\hline & STR & E & $\mathrm{CB}$ & $E^{*}$ & $E^{*}$ & $E^{*}$ & $\mathrm{E} / \mathrm{CB}$ & $\mathrm{CB}$ & $\mathrm{E} / \mathrm{CB}$ & $E^{*}$ & $E^{*}$ & $E^{*}$ \\
\hline \multirow[t]{21}{*}{ B } & Locus & & & & & & & & & & & \\
\hline & D7Mit117 & E & E & E & E & E & CB & E & $\mathrm{CB}$ & E & $\mathrm{CB}$ & E \\
\hline & D7Mit267 & E & E & E & $\mathrm{E} / \mathrm{CB}$ & E & $\mathrm{CB}$ & E & $\mathrm{CB}$ & E & $\mathrm{E}$ & E \\
\hline & D7Mit309 & E & E & E & $\mathrm{CB}$ & E & $\mathrm{CB}$ & E & $\mathrm{CB}$ & E & $\mathrm{CB}$ & $\mathrm{CB}$ \\
\hline & D7Mit83 & E & $\mathrm{CB}$ & E & $\mathrm{CB}$ & $\mathrm{CB}$ & $\mathrm{CB}$ & E & $E$ & E & $E$ & $\mathrm{E}$ \\
\hline & D7Mit120 & E & $\mathrm{CB}$ & E & $\mathrm{CB}$ & $\mathrm{CB}$ & $\mathrm{CB}$ & E & E & E & $\mathrm{CB}$ & $\mathrm{CB}$ \\
\hline & D7Mit318 & E & $\mathrm{CB}$ & E & E & $\mathrm{CB}$ & $\mathrm{CB}$ & E & E & E & $\mathrm{CB}$ & $\mathrm{CB}$ \\
\hline & D7Mit62 & E & $\mathrm{CB}$ & $\mathrm{CB}$ & E & $\mathrm{CB}$ & $\mathrm{CB}$ & E & CB & E & $\mathrm{CB}$ & $\mathrm{CB}$ \\
\hline & D7Mit37 & E & $\mathrm{CB}$ & $\mathrm{CB}$ & $\mathrm{E} / \mathrm{CB}$ & $\mathrm{CB}$ & $\mathrm{CB}$ & E & $\mathrm{CB}$ & $\mathrm{CB}$ & $\mathrm{E}$ & E \\
\hline & D7Mit130 & E & E & $\mathrm{CB}$ & $\mathrm{CB}$ & $\mathrm{CB}$ & $\mathrm{CB}$ & E & $\mathrm{CB}$ & $\mathrm{CB}$ & E & E \\
\hline & D7Mit66 & E & $\mathrm{CB}$ & $\mathrm{CB}$ & $\mathrm{E} / \mathrm{CB}$ & $\mathrm{CB}$ & E & E & E & $\mathrm{CB}$ & E & E \\
\hline & D7Mit68 & $\mathrm{CB}$ & $\mathrm{CB}$ & $\mathrm{CB}$ & $\mathrm{E}$ & $\mathrm{CB}$ & E & E & $\mathrm{CB}$ & $\mathrm{CB}$ & E & E \\
\hline & D7Mit333 & $\mathrm{CB}$ & $\mathrm{CB}$ & $\mathrm{CB}$ & E & $\mathrm{E}$ & E & E & $\mathrm{CB}$ & $\mathrm{CB}$ & E & $\mathrm{CB}$ \\
\hline & D7Mit340 & E & $\mathrm{E}$ & $\mathrm{E}$ & $\mathrm{CB}$ & E & $\mathrm{CB}$ & $\mathrm{CB}$ & $\mathrm{CB}$ & $\mathrm{E}$ & E & $\mathrm{CB}$ \\
\hline & D14Mit78 & $\mathrm{CB}$ & $\mathrm{CB}$ & $\mathrm{CB}$ & $\mathrm{E}$ & $\mathrm{CB}$ & $\mathrm{CB}$ & E & $\mathrm{CB}$ & $\mathrm{CB}$ & $\mathrm{CB}$ & $\mathrm{E}$ \\
\hline & D14Mit14 & $\mathrm{CB}$ & E & $\mathrm{CB}$ & E & E & $\mathrm{CB}$ & E & $\mathrm{CB}$ & $\mathrm{CB}$ & $\mathrm{CB}$ & E \\
\hline & D14Mit140 & $\mathrm{CB}$ & E & E & $\mathrm{CB}$ & E & $\mathrm{CB}$ & $\mathrm{CB}$ & $\mathrm{CB}$ & E & E & E \\
\hline & D14Mit234 & E & E & E & E & E & $\mathrm{CB}$ & $\mathrm{CB}$ & $\mathrm{CB}$ & E & E & E \\
\hline & D14Mit115 & E & E & E & $\mathrm{CB}$ & $\mathrm{CB}$ & $\mathrm{CB}$ & $\mathrm{E}$ & $\mathrm{CB}$ & E & $\mathrm{CB}$ & $\mathrm{E}$ \\
\hline & D14Mit92 & $\mathrm{CB}$ & E & $\mathrm{CB}$ & $\mathrm{CB}$ & E & $\mathrm{CB}$ & $\mathrm{CB}$ & $\mathrm{CB}$ & E & $\mathrm{CB}$ & $\mathrm{CB}$ \\
\hline & Centromere $14^{\#}$ & $\mathrm{CB}$ & $\mathrm{CB}$ & $\mathrm{CB}$ & $\mathrm{CB}$ & $\mathrm{CB}$ & $\mathrm{CB}$ & $\mathrm{CB}$ & $\mathrm{CB}$ & $\mathrm{CB}$ & $\mathrm{CB}$ & $\mathrm{E}$ \\
\hline
\end{tabular}

Table 3

Map manager QTL analysis. Parameter - the quantitative trait (QT) with $\mathrm{P}<0.001$; Marker chromosomal marker linked to the QT; LRS - Likelihood ratio statistic; \% - percent of total trait variance explained by QTL at this locus; P - P value for LRS; suggestive, significant, highly significant - threshold values obtained after permutation test for the peak LRS; peak LRS - the highest LRS value taken from interval mapping

\begin{tabular}{|c|c|c|c|c|c|c|c|c||}
\hline Parameter & Marker & LRS & $\%$ & $\mathrm{P}$ & Suggestive & Significant & $\begin{array}{c}\text { Highly } \\
\text { significant }\end{array}$ & Peak LRS \\
\hline \hline lnVAP & D7Mit309 & 10.9 & 63 & 0.00096 & 3.7 & 11.5 & 16.8 & 10.9 \\
\hline InBCF & D7Mit267 & 16.9 & 79 & 0.00004 & 3.6 & 10.6 & 17.7 & 18.1 \\
\hline lnLIN & D14Mit234 & 10.6 & 62 & $0.00113^{*}$ & 2.9 & 11.5 & 24.4 & 11.1 \\
\hline
\end{tabular}

* - the P value exceeds the critical 0,001 value for a single locus 

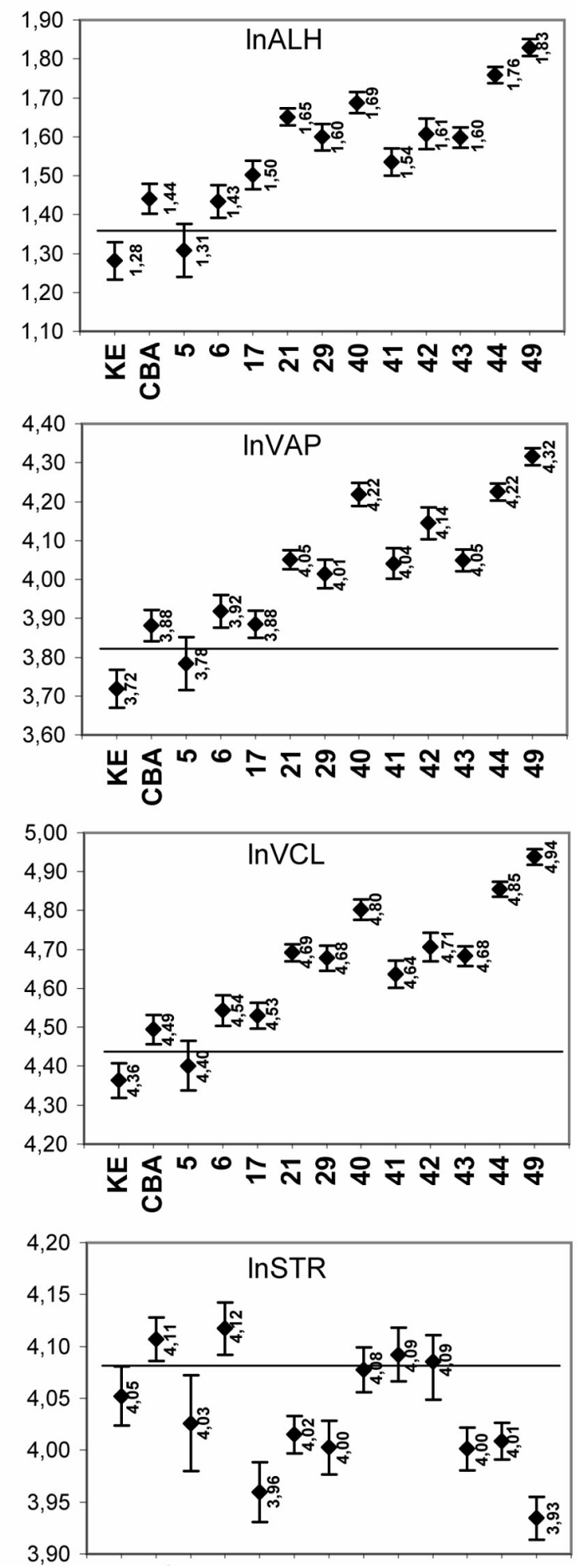
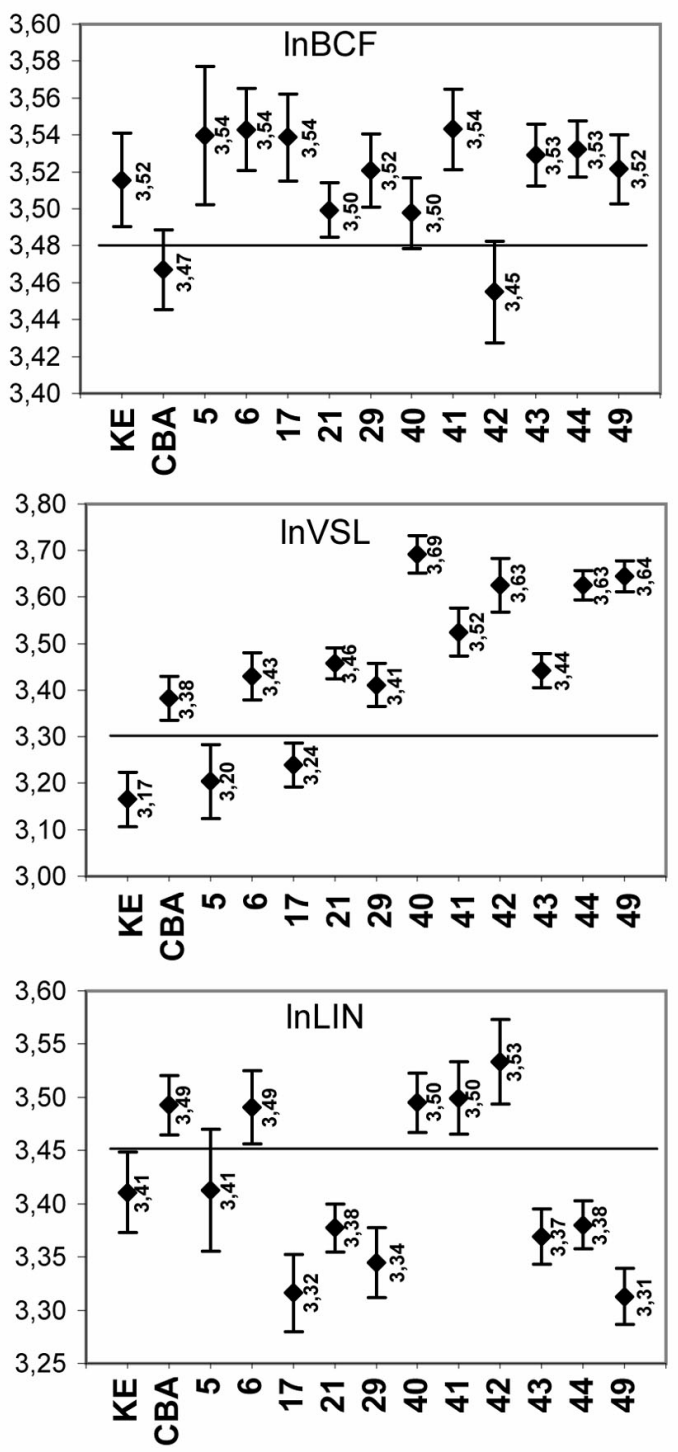

Fig. 1. Mean values (in natural logarithmic transformation) of sperm motility parameters in progenitor (KE, CBA) and RI strains. Mean values are given near to the data points, bars represent confidence intervals of $95 \%$. Horizontal line is a conceptual visualization from the ANOVA analysis and represents the critical values dividing the KE- and CBA-inherited trait values.

variance. Another QTL linked to the D7Mit309 marker at $7 \mathrm{q} 16$ region affected VAP parameter values (LRS=10.9 and 63\%). After empirical determination of LRS critical values with the permutation test, these two QT loci were further examined with the interval mapping procedure. Analysis revealed a suggestive linkage level (peak LRS $=10.9$ was lower than the significant threshold 11.5) of the QTL at the D7Mit309 marker locus with VAP. The peak LRS $=18.1$ for the association of the QTL at D7Mit267 with BCF was greater than the highly significant threshold (17.7). In addition the linkage between D14Mit234 and LIN was analyzed. A LRS $=10.6$ was obtained but the $\mathrm{P}=0,00113$ was over the critical $\mathrm{P}$ for a single locus. However, the permutation test and the interval mapping was done. The significant threshold (11.5) was over the peak LRS (11.1) (Table 3). 


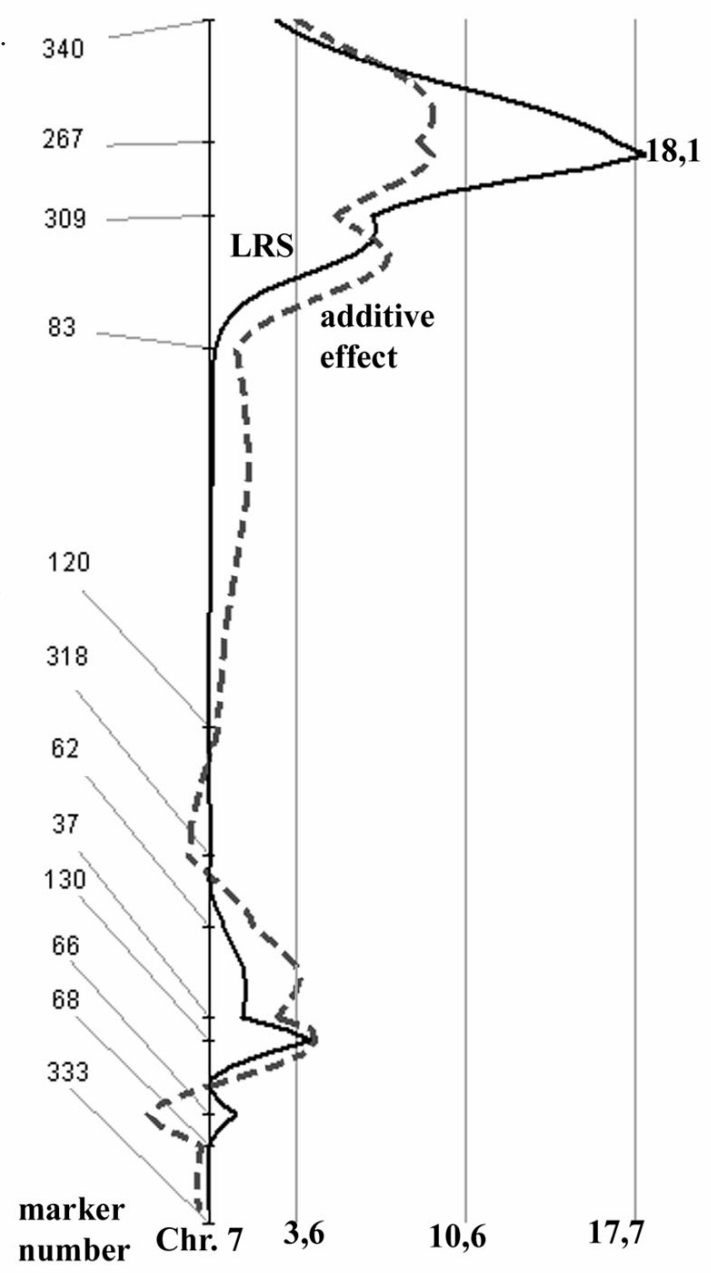

Fig. 2. Interval mapping for $\mathrm{BCF}$ on chromosome 7, constrained by the additive model using the Kosambi map function with no control for other QTLs, made with Map Manager QTX. LRS - likelihood ratio statistic (solid line); additive effect - the additive regression coefficient for the association (dashed line); 18.1 - peak LRS; 3.6, 10.6, 17.7suggestive, significant and highly significant threshold, respectively.

\section{Discussion}

Spermatozoa movement is one of the critical parameters of sperm quality. There are several reports that human fertility decreases continuously (WHO 1987; HORAK et al. 2003), therefore knowledge of the genetic factors influencing sperm quality parameters (i.e. sperm movement) is very important. Here, an attempt was made to find a relationship between the quantitative traits (different sperm motility parameters) and regions on chromosome 7 and 14 in mice. Two inbred strains, $\mathrm{KE}$ and $\mathrm{CBA} / \mathrm{Kw}$, were found to differ significantly in all sperm movement parameters analyzed with CASA after $1.5 \mathrm{~h}$ of incubation, therefore recombinant inbred strains derived from these two progenitor strains were applied to the mapping procedure. A period of $1.5 \mathrm{~h}$ of incubation was chosen because there is evidence that it takes about
$1.5 \mathrm{~h}$ for mice spermatozoa to undergo capacitation in vitro (NEILL \& OLDS-CLARKE, 1987). An SDP table was made for inheritance of analyzed traits (Table 2A) and the Map Manager QTX (MANLY et al. 2001) software was used to determine the coinheritance of analyzed movement parameters and SSLP markers (Table 2B). This program enables the estimation of the influence of genetic and environmental factors on the quantitative trait (marker regression test). In a second step, it determines the QTLs (interval mapping). Moreover, the permutation test establishes the significance thresholds for the obtained LRS. After the QTL screening, a highly significant correlation was found only in the case of the BCF parameter and chromosome region 7q11 (Fig. 2). The high LRS score (18.1) and $79 \%$ of the total trait variance explained by QTL at this locus suggests that this trait depends more on genetic than environmental factors. In other words, it is highly possible that the BCF value is influenced by the gene(s) near the D7Mit267 marker.

Initial searching into the MGI database resulted in three candidate genes, of which Usf2, the transcription factor responsible for male infertility in mice (SIRITO et al. 1998), is located in 7q11. Two other genes influencing gamete quality were found close to this region: testis specific aurora kinase $\mathrm{C}$ (Aurkc) (TSENG et al. 1998; HU et al. 2000) and tyrosine kinase receptor (Axl) (LU et al. 1999). Other preliminary experiments carried out in the authors' Department indicated that the BCF value correlates with the in vitro fertilization efficiency in mice (data not published). It should be noted that the Gpi-1 located in the 7q11 correlates, as mentioned in the Introduction, with oocyte maturation (POLAŃSKI 1997). It may be that this region contributes generally to gamete production.

\section{References}

BAILEY D. W. 1971. Recombinant inbred strains. Transplantation 11: 325-327.

BLAKE J. A., RichaRdSON J. E., BUlt C. J., KADIN J. A., EPPIG J. T., the Mouse Geneome Database Group. 2002. The Mouse Genome Database (MGD): the model organism database for the laboratory mouse. Nucleic Acids Res. 30: 113-115.

EPPig J. T., BLAKE J. A., BuRKhart D. L., GOldSMith C. W., LUTZZ C. M., SMITH C. L. 2002. Corralling conditional mutations: a unified resource for mouse phenotypes. Genetics 32: 63-65.

HiRANO Y., SHIBAHARA H., OBARA H., SUZUKI T., TAKAMIZAWA S., YAMAGUCHI C., TSUNODA H., SATO I. 2001. Relationship between sperm motility characteristics assisted by the computer-aided sperm analysis (CASA) and fertilization rates in vitro. J. Assist. Reprod. Genet. 18: 213-218.

HORAK S., POLAŃSKA J., WIDLAK P. 2003. High levels of bulky DNA adducts in human sperm correlate with impaired fertility. Acta. Biochim. Pol. 50: 197-203.

Hu H. M., Chuang C. K., LeE M. J., Tseng T. C., TANG T. K. 2000. Genomic organization, expression and chromo- 
some localization of a third aurora-related kinase gene, aie1. DNA Cell Biol. 19: 679-688.

KALETA E. 1977. Influence of genetic factors on the fertilization of mouse ova in vitro. J. Reprod. Fertil. 51: 375-381.

King L. M., Holsberger D. R., Donoghue A. M. 2000 Correlation of CASA velocity and linearity parameters with sperm mobility phenotype in turkeys. J. Androl. 21: 65-71.

KRZANOWSKA H. 1970. Relation between fertilization rate and penetration of eggs by supplementary spermatozoa in different mouse strains and crosses. J. Reprod. Fertil. 22: 199-204.

KRZANOWSKA H., POLAŃSKI Z., WABIK-ŚLIZ B., STYRNA J. 1994. Research News. Mouse Genome 92: 507

KRZANOWSKA H., STYRNA J., WABIK-ŚLIZ B. 1995. Analysis of sperm quality in recombinant inbred mouse strains: correlation of sperm head shape with sperm abnormalities and with the incidence of supplementary spermatozoa in the perivitelline space. J. Reprod. Fertil. 104: 347-354.

LANDER E., KRUGLYAK L. 1995. Genetic dissection of complex traits: guidelines for interpreting and reporting linkage results. Nat. Genet. 11: 241-247.

LENARTOWICZ M., WÓJCIK A. 1998. Non-random segregation of 14-chromosome in recombinant inbred strains derived from $\mathrm{KEXCBA} / \mathrm{Kw}$ inbred strains of mice accessed by G-banding and FISH method. J. Appl. Genet. 39A: 142.

LU Q., GORE M., ZHANG Q., CAMENISCH T., BOAST S., CASAGRANDA F., LAI C., SKINNER M. K., KLEIN R., MATSUSHIMA G. K., EARP H. S., GOFF S. P., LEMKE G. 1999. Tyro-3 family receptors are essential regulators of mammalian spermatogenesis. Nature 22: 723-728.

Manly K. F., Cudmore R. H. Jr., Meer J. M. 2001. Map Manager QTX, cross-platform software for genetic mapping. Mamm. Genome 12: 930-932.

NEILL J. M., OLDS-ClARKE P. 1987. A computer-assisted assay for mouse sperm hyperactivation demonstrates that bicarbonate but not bovine serum albumin is required. Gamete Res. 18: 121-140.

OLDS-ClARKE P. 1986. Motility characteristics of sperm from the uterus and oviducts of female mice after mating to congenic males differing in sperm transport and fertility. Biol. Reprod. 34: 453-467.
POLAŃSKI Z. 1997. Genetic background of the differences in timing of meiotic maturation in mouse oocytes: a study using recombinant inbred strains. J. Reprod. Fertil. 109: 109-114.

RAFIŃSKI J., STYRNA J., KRZANOWSKA H. 1991. Analysis of genetic markers in the recombinant inbred strains developed from $\mathrm{CBA} / \mathrm{Kw}$ and $\mathrm{KE}$ mouse strains. Zwierzęta laboratoryjne 28: 25-30.

Ren D., Navarro B., Perez G., Jackson A. C., Hsu S., Shi Q., TILLY JL., CLAPHAM D. E. 2001. A sperm ion channel required for sperm motility and male fertility. Nature 413: 603-609.

SAMPSON S. B., Higgins D. C., Elliot R. W., TAYlor B. A. LUEDERS K. K., KOZA R. A., PAIGEN B. 1998. An edited linkage map for the AXB and BXA recombinant inbred mouse strains. Mamm. Genome 9: 688-694.

SATO M., OHTA R., KoJIMA K., ShiRota M. 2002. Differences in sperm motion between high- and low-shuttlebox avoidance rats (Hatano strains). J. Androl. 23: 250-258.

Shultz K. L., Svenson K. L., Cheach Y., Paigen B., BEAMER W. G. 1996. Strain distribution pattern for SSLP markers in the SWXJ recombinant inbred strain set: chromosome 7-X. Mamm. Genome 7: 526-532.

SiRITO M., LiN Q., DENG J. M., BEhringer R. R., SAWADOGO M. 1998. Overlapping roles and asymmetrical crossregulation of the USF proteins in mice. Proc. Natl. Acad. Sci. USA 75: 3758-3768.

STYRNA J., MIKSZTAL T., RYPEL-CHRZAN A. 1994. Analysis of genetic markers Svp-1 and Svp-3 in recombinant mouse strains CBXE and EXCB. Folia biol. (Kraków) 42: 135-38.

TAYLOR B. A. 1978. Recombinant inbred strains: use in gene mapping. (In: Origin of Inbred Mice. Morse H.C. ed. Academic Press, New York): 423-438.

Thonneau P., Marchand S., TAllec A., Ferial M. L., DUCOT B., LANSAC J., LOPES P., TABASTE J. M., SPIRA A. 1991. Incidence and main causes of infertility in a resident population $(1,850,000)$ of three French regions (1988-1989). Hum. Reprod. 6: 811-816.

Tseng T. C., Chen S. H., Hsu Y. P., TANG T. K. 1998. Protein kinase profile of sperm and eggs: cloning and characterization of two novel testis-specific protein kinase (AIE1, AIE2) related to yeast and fly chromosome segregation regulators. DNA Cell Biol. 17: 823-833.

World Health Organization. 1987. Fertil. Steril. 47: 964-968. 